\title{
SOCIAL INNOVATION AND COMPETITIVENESS - A LITERATURE REVIEW OF THE THEORETICAL WORK IN THE FIELD
}

\author{
Károly BALATON ${ }^{\mathrm{a}}$, Krisztina VARGA ${ }^{\mathrm{b} *}$ \\ a),b) University of Miskolc, Faculty of Economics, Miskolc, Hungary
}

Please cite this article as:

Balaton, K. and Varga, K., 2017. Social innovation and competitiveness - A literature review of the theoretical work in the field. Review of Economic Studies and Research Virgil Madgearu, 10(2), pp.27-42.

doi: 10.24193/RVM.2017.10.08.
Article History:

Received: 20 July 2017 Accepted: 29 August 2017

Abstract: Competitiveness has become a major topic of economic and business
studies over the last 20 years. In the 1980s, the focus of the study on innovation
and competitiveness was corporate-level analysis. Subsequently, the focus shifted
towards examining the role of larger communities, as the innovation performance
of the community is decisive. The identification and study of actors involved in
the implementation of innovation is of utmost importance for successes, and
creates the need for investigation at multiple levels. In addition to the company's
innovation capabilities, the innovation potential at regional and national level is also
relevant. One of the features of successful companies is the complex interpretation
of innovations (continuous and radical innovations simultaneously), which gives
them a competitive advantage. Innovation is connected to the unique value, creating
the competitive advantage that is decisive for competitiveness of an organization,
region or even national economy. But there is the question: how can innovation be
quantified in the development of competitiveness. In this paper we concentrate on
social innovation and its connection to competitiveness at micro, mezo and macro
level and the paper represents a literature review of the theoretical work in the field. Key words: competitiveness; social innovation; measurement JEL Classification: I31; L1O; O35

(C) 2017 Alma Mater Publishing House. All rights reserved.

* Corresponding author. E-mail address: varga.krisztina@uni-miskolc.hu. 


\section{References}

1. Bahrami, H. and Evans, S., 2005. Super-Flexibility for Knowledge Enterprises. Berlin-Heidelberg: Springer.

2. Barsi, B., 2003. Az információs és kommunikációs technológiák (IKT) hatása a versenyképességre. [The influence of information and communication technologies on competitiveness.] Tér és Társadalom (Space and Society), 17(3), pp.183-197.

3. Benedek, J., Kocziszky, G., Veresné Somosi, M. and Balaton, K. (2015): Regionális társadalmi innováció generálása szakértői rendszer segítségével. [Generating social innovation by using an expert system], Észak-magyarországi Stratégiai Füzetek [North-Hungarian Strategic Papers], 12(2), pp. 4-22.

4. Bernard, A.B., Redding, S.J. and Schott, P.K., 2007. Comparative advantage and heterogeneous firms. Review of Economic Studies, 74(1), pp.31-66.

5. Birchenhall, C., 1995. Modular Technical Change and Genetic Algorithms. Computational Economics, 8, pp.233-253.

6. Bulut, C., Eren, H. and Halac, D.S., 2013. Social Innovation and Psychometric Analysis. Procedia - Social and Behavioral Sciences, 82, pp. 122-130.

7. Chikán, A. and Czakó, E. (eds.), 2009. Versenyben a világgal. Vállalataink versenyképessége az új évezred küszöblén. [Hungarian companies in global competition]. Budapest: Akadémiai Kiadó.

8. Czakó, E., 200o. Versenyképesség iparágak szintjén - a globalizáció tükrében [Competitiveness at industry level - in light of globalization], PhD disszertáció. Budapest: BKÁE Vállalatgazdaságtan Tanszék.

9. Durand, T., Granstrand, O., Herstatt, C., Nagel, A., Probert, D. and Tschirky, H. (eds.), 2004. Bringing Technology and Innovation into the Boardroom. Strategy, Innovation and Competences for Business Value. European Institute for Technology and Innovation Management. Hampshire: Palgrave Macmillan.

10. EC, 2006. Innovation in the national strategic reference frameworks, Working document of the Directorate General for Regional Policy. Available at: http:// ec.europa.eu/regional_policy/archive/innovation/2007/innovation_nsrf.pdf.

11. EC, 2014. Az Európai Unió kutatási és innovációs keretprogramja [Research and innovation framework programme of European Union]. Available at: https:// ec.europa.eu/programmes/horizon2020/sites/horizon2020/files/H2020_HU_ KIo213413HUN.pdf.

12. Ghemawat, P., 2010. Finding your strategy in the new landscape. Harvard Business Review, 88(2), pp.54-60.

13. Gulati, R., Nohria, R. and Wohlgezogen, F., 2010. Roaring out of recession. Harvard Business Review, pp. 62-69. Available at: https://hbr.org/2010/o3/roaring-out-ofrecession.

14. Hakansson, H., 2010. Duels or duets? Characterizing interaction between companies. Paper presented at the 26th IMP Conference: Business Networks - Globality, Regionality, Locality. Budapest: Corvinus University of Budapest, Hungary, 2-4 September.

15. Hakansson, H. and Lind, J., 2004. Accounting and Network Coordination. Accounting, Organizations and Society, 29(1), pp.51-72. 
Review of Economic Studies and Research Virgil Madgearu, 2017, 10(2)

16. Hortoványi, L. and Balaton, K., 2016. A versenyképesség és az innováció vállalati szintü vizsgálata [Enterprise level analysis of competition and innovation]. Vezetéstudomány [Budapest Management Review], XLVII(12), pp.38-45.

17. Hülsmann, M. and Pfeffermann, N., 2011. Strategies and Communications for Innovations. Heidelberg: Springer.

18. Jarjabka, Á. and Lóránd, B., 2010. Az innováció alapjai és megjelenési területei. Available at: http://kikk.hu/attachments/article/810/Innov\%C3\%A1ci\%C3\%B3\%20 menedzsment\%2ok\%C3\%A9pz\%C3\%A9s\%20anyaga.PDF.

19. Leavitt, H.J., 1987. Corporate Pathfinders - Building Vision and Values into Organizations. Harmondworth, UK: Penguin Books.

20. Lessa, B.S., Alves Souza, A.C. and da Silva-Filho, J.C.L., 2016. Education in cooperative cells as a social innovation: a case study in the Brazilian semiarid. $R A I$ Revista de Administração e Inovação, 13(3), pp.166-175. https://doi.org/10.1016/j. rai.2016.06.004.

21. March, J.G., 1991. Exploration and Exploitation in Organizational Learning. Organization Science, 2(1), pp.71-87.

22. Nemes, G. and Varga, Á., 2015. Társadalmi innováció és társadalmi tanulás a vidékfejlesztésben - sikerek, problémák, dilemmák [Social innovation and social learning in rural development]. In Veresné, S.M. (ed.), 2015. Mérleg és Kihívások [Balance and Challenges], IX. Nemzetközi Tudományos Konferencia [IX. Internatonal Scientific Conference], Miskolc, pp.434-444.

23. Piskóti, I., 2012. Marketing képességek szerepe az innovációs versenyelőnyök fenntartásában [The role of marketing capabilities in maintaining innovative comparative advantages] (pdf). Available at: https://emok.hu/tanulmanykereso/konferenciakotetek/d422:marketing-kepessegek-szerepe-az-innovaciosversenyelonyok-fenntartasaban/pdf.

24. Pol, E. and Ville, S., 2009. Social innovation: Buzz word or enduring term? The Journal of Socio-Economics, 38, pp.878-885.

25. Porter, M.A., 1980. Competitive strategy. New York: The Free Press.

26. Ringland, G., Sparrow, O. and Lustig, P., 2010. Beyond Crisis - Achieving Renewal in a Turbulent World. Chichester, UK: Wiley and Sons.

27. Schmitz, B., Krlev, G., Mildenberger, G., Bund, E. and Hubrich, D., 2013. Paving the Way to Measurement - A Blueprint for Social Innovation Metrics. A deliverable of the project: The theoretical, empirical and policy foundations for building social innovation in Europe (TEPSIE), European Commission - 7th Framework Programme.

28. Szilágyi, G., 2008. A versenyképesség mérése a nemzetközi összehasonlítások módszertanának tükrében [Measuring competitiveness in light of international comparative methodology]. Statisztikai Szemle [Statistical Review], 86(1), pp.5-21.

29. Török, Á., 1999. A versenyképesség és a technológiamenedzsment [Competitiveness and Technology Management]. In Inzelt, A., 1999. Bevezetés az innovációmenedzsmentbe [Introduction to Innovation Management]. Budapest: Müszaki Könyvkiadó, pp.74-95.

30. Tushman, M.L. and Anderson, P., 2004. Managing Strategic Innovation and Change. 2nd edition. Oxford: Oxford University Press. 